\title{
ПРО ДІЯЛЬНІСТЬ ВІДДІЛУ ПСИХОЛОГІї ІНСТИТУТУ ПЕДАГОГІЧНОЇ ОСВІТИ І ОСВІТИ ДОРОСЛИХ ІМЕНІ ІВАНА ЗЯЗЮНА НАПН УКРАЇНИ В УМОВАХ ЕПІДЕМІЧНОЇ ЗАГРОЗИ
}

https://doi.org/10.37472/2707-305X-2020-2-1-7-2
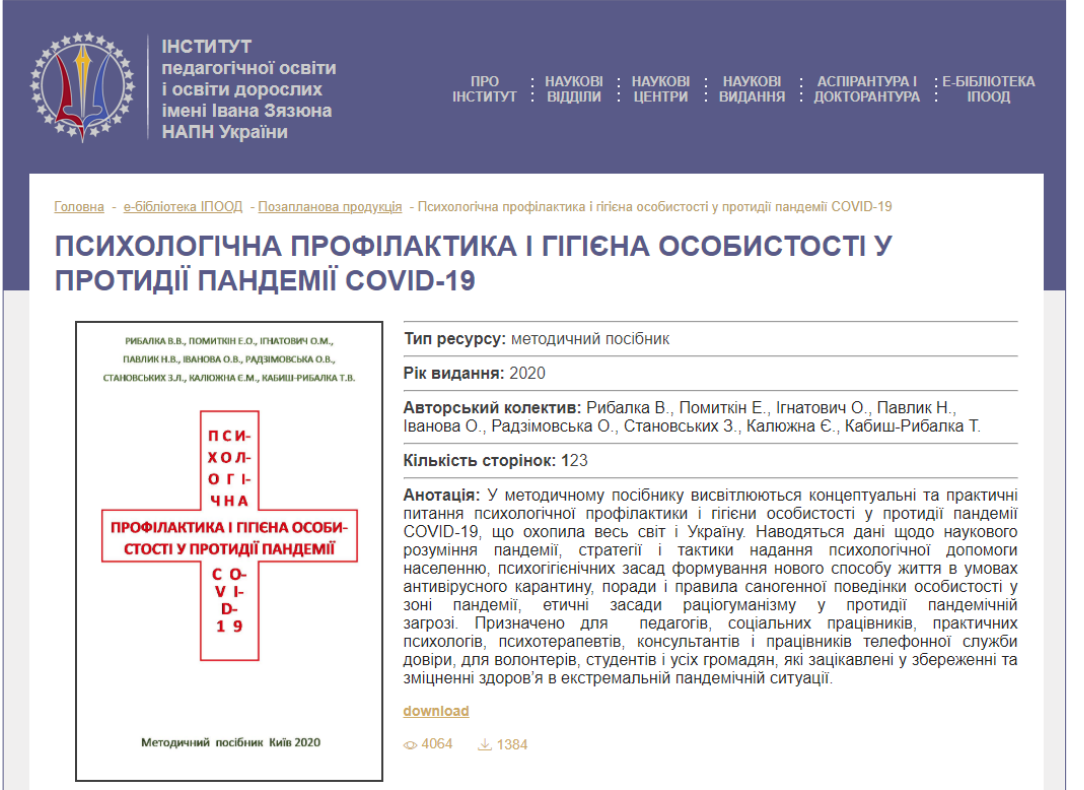

ІГНАТОВИЧ Олена Михайлівна

доктор психологічних наук, старший науковий співробітник, завідувач відділу психології праці Iнституту педагогічної освіти i освіти дорослих імені Івана Зязюна Національної академії педагогічних наук України, м. Київ, Україна

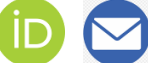

Анотація. Представлено результати діяльності відділу психології праці Інституту педагогічної освіти $і$ освіти дорослих імені Івана Зязюна Національної академії педагогічних наук України в умовах епідемічної загрози. Подано інформацію про роботу вчених відділу в дистаниійному форматі, зокрема про методичний посібник «Психологічна профілактика і гігієна особистості у протидії пандемії COVID-19», проведення семінару-практикуму "Психопрофрілактика тривожних станів: практики, що підтримують внутрішні ресурси», та діяльність Психологічного консультативно-тренінгового центру тощо.

Ключові слова: пандемія COVID-19; психологічна профрілактика; профрілактика тривожних станів.

у період уведення загальнонаціонального карантину в Україні відділ психології праці Інституту педагогічної освіти і освіти дорослих імені Івана Зязюна НАПН України продовжує свою роботу в дистанційному форматі. На цей час здійснюється робота над актуальною і необхідною для суспільства науковою продукцією «Психологічна профілактика і гігієна особистості у протидії пандемії COVID-19» (2020).

У методичному посібнику висвітлено концептуальні та практичні питання психологічної профілактики і гігієни особистості у протидії пандемії COVID-19, що охопила весь світ і Україну. Наводяться дані щодо наукового розуміння пандемії, стратегії і тактики надання психологічної допомоги населенню, психогігієнічних засад формування нового способу життя в умовах антивірусного карантину, поради і правила саногенної поведінки особистості у зоні пандемії, етичні засади раціогуманізму у протидії пандемічній загрозі.

Методичний посібник призначено для педагогів, соціальних працівників, практичних психологів, психотерапевтів, консультантів і працівників телефонної служби довіри, для волонтерів, студентів і всіх громадян, які зацікавлені у збереженні та зміцненні здоров'я в екстремальній пандемічній ситуації. 
Водночас наукові працівники відділу здійснили переклад змісту методичного посібника «Психологічна профілактика і гігієна особистості у протидії пандемії COVID-19» російською мовою, у травні планується завершити переклад його змісту англійською, а також започатковано Всеукраїнську акцію «Психопедагогічна ТОЛОКА AHTI-COVID-19», Міжнародний проєкт «Психологи і педагоги світу у протидії пандемії: INTER-ANTI-COVID-19» та створення інтернетпосібника «Психологія і педагогіка у протидії пандемії COVID-19» у 6 частинах (за заг. ред. Н.Г. Ничкало, С.Д. Максименка, Л.Б. Лук'янової, коорд. і ред. інтернет-проєкту В.В. Рибалка, колектив авторів - більше 30 учених, учителів, практичних психологів і соціальних працівників з різних регіонів України).

31 березня 2020 р. наукові працівники відділу психології праці Інституту організували та провели семінар-практикум «Психопрофілактика тривожних станів: практики, що підтримують внутрішні ресурси» на онлайн-платформі ZOOM, модератором якого була А.М. Шевенко, молодший науковий співробітник відділу. У роботі семінару-практикуму взяли участь понад 20 осіб із різних наукових установ і закладів освіти. Мета заходу - допомогти знизити рівень тривожності у період перебування на вимушеному карантині, підтримати ресурсність людини за допомогою різних психологічних вправ і практик. Серед доповідачів були науковці, вчителі, психологи, зокрема: доктор психологічних наук, професор Едуард Олександрович Помиткін; доктор психологічних наук Олена Михайлівна Ігнатович; кандидат психологічних наук Оксана Віталіївна Радзімовська; молодший науковий співробітник відділу Іван Віталійович Заєць; аспірантка відділу Наталя Володимирівна Четверікова; практичний психолог Оксана Анатоліївна Даюб та ін.

Е.О. Помиткін висвітлив питання глобального уявлення про ситуацію пандемії, висловив припущення щодо причин цього явища та реакцій людства на події і розкрив основи надання первинної допомоги людям, які потребують психологічної підтримки у ситуації емоційного виснаження. У доповіді він представив карту емоцій, що складається з 300 варіантів емоційних станів, а також запропонував для використання серед населення засобів урізноманітнення людиною емоційного спектру власних переживань, розширення емоційної палітри щоденного життя. Т.І. Горенюк, біолог і консультант щодо питань здоров'я, надала інформацію про адаптацію населення до умов вимушеної ізоляції під час карантину, що призводить до підвищення тривожності. Вона зазначила, що тривожні стани віднімають ресурси, знижують імунітет, призводять до часткового чи повного виснаження людини. О.М. Ігнатович розкрила особливості перебування людини в паніці, способи попередження та подолання паніки (індивідуалізація, раціоналізація психіки). О.В. Радзімовська охарактеризувала стратегії і тактики активізації власного емоційного ресурсу та представила засоби атртерапевтичних технік і музичної релаксації. І.В. Заєць окреслив ризики перенесення вимушеної ізоляції особами різних типів темпераменту. Він детально висвітлив методики, що діагносту-
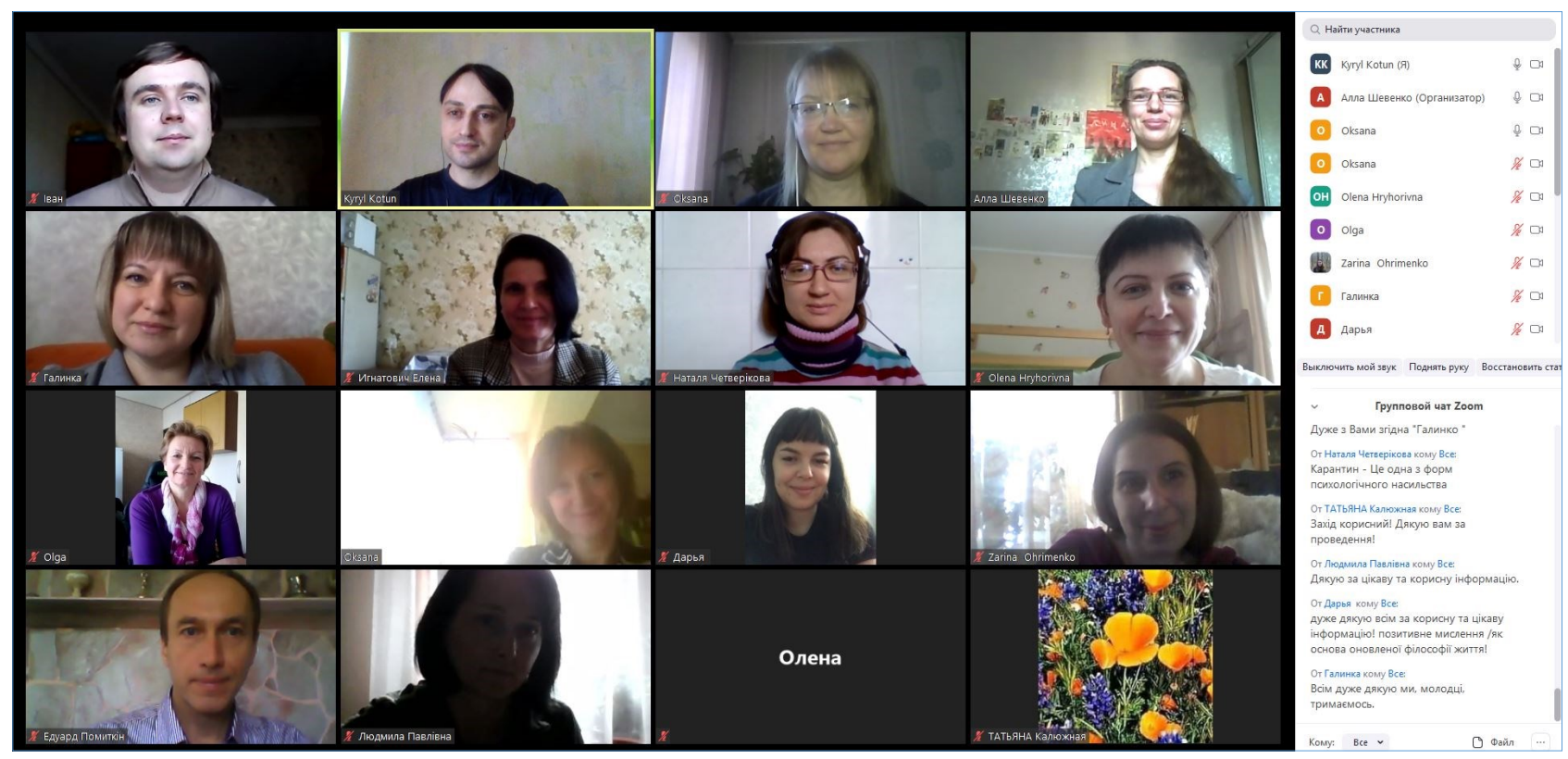
ють рівень тривожності, а також особливості їх застосування та інтерпретації шкал. А.М. Шевенко проаналізувала чотири типи перебування у карантині: депресивно-пасивний; агресивно-пасивний; безвідповідальний; свідомий. Нею були визначені їх особливості та ситуації, що провокують тривожність, зокрема це невизначеність, ізоляція, байдужість оточуючих, багатозадачність, швидкі зміни тощо. Так, учасники заходу з'ясували виклики сьогодення та визначили, що вони провокують конфлікт, який може розглядатися як руйнування, так і відлік росту та нових можливостей. Обговорено та запропоновано засоби профілактики тривожності. Надалі вчені відділу психології праці Інституту планують продовжувати практику організації вебінарів, семінарів, консультацій.

В умовах карантину та вимушеної самоізоляції населення наукові працівники відділу на базі Психологічного консультативно-тренінгового центру Інституту педагогічної освіти і освіти дорослих імені Івана Зязюна НАПН України здійснюють онлайн-консультативну роботу 3 надання психологічної допомоги, спрямованої на захист духовного, психічного, соціального здоров'я особистості засобами духовно-психологічної просвіти, практичної психології і психотерапії. Зокрема, кандидатом психологічних наук 3.Л. Становських проведено більш ніж 20 дистанційних консультацій для населення серед категорій здорових людей і людей з хронічними хворобами за такою тематикою: «Базова інформація про коронавірус»; «Особливості отримання медичних послуг в умовах карантину»; «Психологічна підтримка». Серед основних проблем, з якими звертаються клієнти до психологів центру, є такі:

1) страх інфікування загалом і при зверненні до лікарні;

2) труднощі фізичні від гіподинамії та психологічні - через зміни у способі життя;

3) труднощі доступу до належного обов'язкового лікування через транспортні обмеження;

4) відсутність необхідної інформації про доступ до лікарів або запроваджені Міністерством охорони здоров'я України алгоритми;

5) побутові труднощі для людей, які знаходяться на тривалому лікуванні у стаціонарах (контактні хвороби).

Для вирішення окреслених питань доцільними видами допомоги людям є: психологічна підтримка; психологічні рекомендації; алгоритми вирішення проблемних ситуацій; висвітлення інформації про місцеві ресурси для розв'язання нагальних проблем.

Е.О. Помиткін, 3.Л. Становських, О.В. Радзімовська, А.М. Шевенко та ін. здійснюють консультування клієнтів Психологічного консультативнотренінгового центру з питань:

- суїцидальної поведінки;

- базової інформації щодо коронавірусу;

- психокорекції стресового стану та панічних настроїв;

- надання алгоритмів емоційної і поведінкової саморегуляції в умовах карантину;

- надання алгоритмів звернення за медичною допомогою у випадку захворювання;

- консультування батьків і педагогів про те, як говорити з дітьми про коронавірусну інфекцію та карантин;

- консультування про особливості перебування на карантині та підтримку емоційного стану батьків і дітей;

- розваг у квартирі - що краще обрати;

- використання освітніх платформ для дітей і батьків.

Наукові працівники відділу забезпечили організацію дистанційної роботи восьми викладачів для навчання аспірантів (спеціальність «053 Психологія»), що включала: узгодження планів, розкладу та форм дистанційної роботи; контроль освітнього процесу, складення реального графіку дистанційних занять онлайн; проведення сесійних занять із аспірантами (З.Л. Становських, В.В. Рибалка, Е.О. Помиткін, О.В. Радзімовська). Здійснювалася дистанційна робота для студентів Білоцерківського інституту неперервної професійної освіти ДЗВО «Університет менеджменту освіти» - навчальнотренінгові заняття зі студентами спеціальності «053 Психологія» 3 навчальних дисциплін «Психологічні технології вищої освіти», «Теоретико-методологічні проблеми психології» (О.М. Ігнатович).

Триває робота над плановою продукцією, що включає: аналітичні матеріали «Розвиток психологічної готовності педагогічного персоналу допрофесійної діяльності в умовах нової української школи» (О.М. Ігнатович, Е.О. Помиткін, В.В. Рибалка, 3.Л. Становських, Н.В. Павлик, О.В. Радзімовськ, О.В. Іванова, Г.П. ТатауроваОсика, А.М.Шевенко, І.В. Заєць); виробничопрактичну продукцію - практичні посібники «Психолого-методичний супровід професійної 
діяльності педагога нової української школи» (Е.О. Помиткін, 3.Л. Становських), «Психологія професійної діагностики та професійного консультування» (О.М. Ігнатович, Г.П. Татаурова-Осика, А.М. Шевенко); методичний посібник «Психологічні засоби професійного розвитку педагога нової української школи» (Н.В. Павлик, О.В. Іванова); методичні рекомендації «Психологія розвитку особистісної готовності педагогів до професійної діяльності» (В.В. Рибалка), «Психологічні засоби виявлення та реалізації емоційного ресурсу вчителя в умовах НУШ» (О.В. Радзімовська), «Науковопрактичне забезпечення профдіагностичної і профконсультативної діяльності» (І.В. Заєць, А.М. Шевенко).

У перспективі вчені відділу психології праці Інституту педагогічної освіти і освіти дорослих імені Івана Зязюна НАПН України планують проведення $X$ Всеукраїнських психологопедагогічних читань, присвячених пам'яті
Б.О. Федоришина, застосування IКТ та комп'ютерних програм для реалізації професійної діяльності в дистанційному форматі тощо.

\section{СПИСОК ВИКОРИСТАНИХ ДЖЕРЕЛ}

Рибалка, В.В., Помиткін, Е.О., Ігнатович, О.М., Павлик, Н.В., Іванова, О.В., Радзімовська, О.В., Становських, 3.Л., Калюжна, Є.М., \& Кабиш-Рибалка, Т.В. (2020). Психологічна профрілактика і гігієна особистості у протидії пандемії COVID-19 : методичний посібник (В.В. Рибалка, ред.). Київ: Інститут педагогічної освіти і освіти дорослих імені Івана Зязюна НАПН України. http://ipood.com.ua/e-library/pozaplanovaprodukciya/psihologichna-profilaktika-i-gigienaosobistosti--u-protidi-pandemi-covid-19/

Семінар-практикум «Психопрофрілактика тривожних станів: практики, що підтримують внутрішні ресурси» (2020). http://ipood.com.ua/novini/seminar -praktikum-psihoproflaktika-trivojnih-stanv-praktiki,scho-pdtrimuyut-vnutrshn-resursi/

Діяльність психологічного консультативнотренінгового центру (2020). http://ipood.com.ua/ novini/diyalnist-psihologichnogo-konsultativnotreningovogo-centru-850/

\section{ON THE ACTIVITY OF THE PSYCHOLOGY OF LABOR DEPARTMENT OF THE IVAN ZIAZIUN INSTITUTE FOR TEACHER EDUCATION AND ADULT EDUCATION OF NAES OF UKRAINE UNDER THE EPIDEMIC THREAT}

\section{Olena Ihnatovych}

DSc in Psychology, Senior Researcher, Head of the Psychology of Labour Department, Ivan Ziaziun Institute for Teacher Education and Adult Education of the National Academy of Educational Sciences of Ukraine, Kyiv, Ukraine

Abstract. The results of the activity of the Psychology of Labour Department of the Ivan Ziaziun Institute for Teacher Education and Adult Education of the National Academy of Educational Sciences of Ukraine under the epidemic threat are presented; information on the work of the Department's researchers in distance mode, in particular, on the methodological manual "Psychological Prevention and Personal Hygiene in the Fight against the COVID-19 Pandemic", workshop "Psychoprophylaxis of Anxiety States: Internal Resources Support Practices", activities of the Psychological Consulting and Training Centre, etc.

Keywords: COVID-19 pandemic; psychological prevention; prevention of anxiety states. 